\section{Hematological Values and Body, Heart and Liver Weights of Male and Female Broiler Embryos of Young and Old Breeder Eggs}

Q Author(s)
Morita VS'
Boleli IC
Cargnelutti Filho A ${ }^{2}$
1 Universidade Estadual de São Paulo- UNESP,
Faculdade de Ciências Agrárias e
Veterinárias. Brasil, Campus de Jaboticabal.
2 Universidade Federal do Rio Grande do Sul,
Instituto de Matemática, Departamento de
Estatística.

Mail Address

\section{Isabel C. Boleli}

Universidade Estadual de São Paulo - UNESP. Faculdade de Ciências Agrárias e Veterinárias. Departamento de Morfologia e Fisiologia Animal

Via de Acesso Prof. Paulo D. Castellani, s/n, 14.884-900. Jaboticabal, São Paulo, Brazil.

Tel. 00-55-0x16-32092654

E-mail: icboleli@fcav.unesp.br

\section{Keywords}

Blood parameters, breeder age, embryos, eggshell porosity and conductance, sex.

\section{ABSTRACT}

This study analyzed broiler breeder age (29 or 60 wk-old) effects on physical characteristics of eggs (initial mass, mass loss, volume, diameter, surface area and density) and of eggshells(weight, volume, thickness, conductance, and porosity ), as well as the influence of embryo sex on hematological parameters and body, liver and heart weights during incubation (at days 13, 15, 18 and 21). Physical parameter values were lower in 29-wk-old broiler breeder eggs than those of 60-wk-old breeders, except for relative eggshell weight, which was higher. In both male and female embryos, erythrocytic parameters and the body, liver, and heart weights increased during the incubation. The embryos and their organs were heavier when derived from 60-wk-old breeder eggs as compared to 29 -wk-old breeder eggs. At hatching, hematocrit values were higher in males than in females. Thrombocytes were the most frequent leukocytes in the blood. Thrombocyte percentage decreased and lymphocyte percentage increased during the last days of incubation. The results showed maternal age influence only on body, heart and liver weights, focal sex-related influence the hematocrit at hatching, and temporal effect of incubation on body and organ weights, as well as on red blood cell count, hematocrit, hemoglobin, plasma glucose, and lymphocytes, which increased during the incubation period, while mean corpuscular volume and thrombocyte values decreased.

\section{INTRODUCTION}

The functional structure of fertile eggs must provide adequate embryo development outside the maternal body. This requires the egg to contain adequate and available nutrients, energy source, and water, as well as to allow gas exchange across the eggshell pores throughout incubation. The avian eggshell is a protective barrier against mechanical shock and microorganisms, and the main source of minerals. In addition, it allows $\mathrm{O}_{2}$ diffusion into the egg and release of $\mathrm{CO}_{2}$ and steam from the eggs into the environment. Gas exchanges in embryos are carried out by the chorioallantoic membrane (Wangensteen \& Rahn, 1970/1971) mainly by diffusion (Metcalfe et al., 1981; Rahn et al., 1987). Gases are exchanged through the eggshell pores, which are unique communication channels between the internal and external egg environment, and have to cross the barriers of the chorioallantoic membrane, outer and inner shell membranes, palisade layer, and cuticle (Wangensteen \& Weibel, 1982; Seymour \& Piiper, 1988). The main limiting features of gas exchange are shell thickness and porosity (Ar et al., 1974).

Maternal physiological conditions during egg production, together with genetic factors, influence eggshell characteristics and, consequently, embryo development (Maiorka et al., 2003). In broilers, it is known that older breeders produce eggs with higher total pore number 
Morita VS, Boleli IC, Cargnelutti Filho A than young breeders (Shanawany, 1984). Eggshell pore size and number are established during egg formation (La Scala, 2003). According to Christensen et al. (1995), changes in eggshell thickness, pore number and diameter decrease the conductance of $\mathrm{O}_{2}$ available for embryo growth.

Nutritional and respiratory deficiencies can be hematologically diagnosed by analyzing the erythrocytic and leukocytic series. Literature data show that organisms are able to respond to stressor agents by eliciting an increase in plasma glucose and hematocrit, a reduction in lymphocyte number and, glycogen level and hepatic index, as well as changes in heterophil: lymphocyte ratio (Barton et al., 1987; Chamblee et al., 1989; Maxwell et al., 1990).

The objectives of the present study were to analyze broiler embryo blood cell counts and body, liver, and heart weights, to determine if there are differences in eggshell structural characteristics between 29- and 60week-old breeders and if these differences, including embryo sex, influence embryo hematological parameters and body and organ weights during the incubation period.

\section{MATERIALS AND METHODS}

Fertile eggs (white eggshell) of $\mathrm{Cobb} 500^{\circledR}$ broiler breeders were collected from the same hens at 29 and 60 weeks of age ( $56 \pm 3.0 \mathrm{~g}$ and $74.6 \pm 2.7 \mathrm{~g}$, respectively) and obtained from a commercial hatchery. Eggs were analyzed and incubated at the Laboratory of Histology and Embryology, Department of Animal Morphology and Physiology, School of Agrarian and Veterinary Sciences, São Paulo State University (UNESP), Jaboticabal campus. The present study was conducted in 2006 and 2007.

The physical characteristics of the egg and eggshell from 29- and 60-wk-old breeders were compared ( $\mathrm{N}$ $=15$ eggs per breeder age). The length of egg longitudinal axis corresponded to the distance between the end of the egg containing the air cell and the pointed end, while its transversal axis was measured transversally to the former and corresponded to maximum width. Both axes were measured in centimeters using a vernier caliper. Initial egg mass (g) was the egg mass measured immediately after puncturing the air cell with a hypodermic needle and injecting distilled water to displace the air volume (Christensen et al., 1996). Egg volume $\left(\mathrm{cm}^{3}\right)$ was determined by the Archimedes principle as the difference in mass between dry egg weight and egg
Hematological Values and Body, Heart and Liver Weights of Male and Female Broiler Embryos of Young and Old Breeder Eggs weight submersed in a graduated test tube of distilled water divided by water density at water temperature (Rahn et al., 1981). Egg surface area $\left(\mathrm{cm}^{2}\right)$ was estimated by the allometric formula: Area = $4.835 \mathrm{~W}^{0.662}$, where $\mathrm{W}$ is initial egg mass (g) (Paganelli et al., 1974). Egg density was obtained by dividing egg mass by egg volume.

Eggshell weight $(\mathrm{g})$ included eggshell membranes, and was obtained after the eggs were emptied, internally washed with water to completely remove the albumen, and dried to a quarter of the temperature for two weeks. Eggshell thickness and pore number per $\mathrm{cm}^{2}$ were obtained from pieces of the eggshell taken from the pointed, equatorial, and enlarged areas of the egg. Eggshell pieces were boiled for 10 minutes in a $5 \% \mathrm{NaOH}$ solution (to remove eggshell cuticle and membranes), rinsed with water, dried, stained for 2 minutes with a water solution of $1 \%$ methylene blue, rinsed again with water, and dried (Rahn et al., 1981). Eggshell thickness did not include membranes, and was measured using a digital micrometer (Mitutoyo - 0.001 $\mathrm{mm}$ accuracy). Mean eggshell thickness was obtained for each individual egg from its shell pieces. The number of pores per $\mathrm{cm}^{2}$ was determined under a stereomicroscope using a reticular eye piece. Mean pore number was also established for each egg based on the values of its three areas. The mean value was multiplied by total egg surface area to estimate the total number of pores per egg. Eggshell volume was calculated by the formula: Volume $=A \times L$, where $A$ is the egg surface area $\left(\mathrm{cm}^{2}\right)$, and $L$ is the thickness of the shell (cm) (Rahn et al., 1981).

Daily egg mass loss and eggshell conductance were analyzed under normal incubation conditions (at $37.5^{\circ} \mathrm{C}$ and $60 \% \mathrm{RH})$. Thirty fertile eggs per breeder age were distributed in two incubators (IP70, Premium Ecológica) with automatic temperature control and egg turning every 2 hours. The relative humidity was measured by an automatic thermo-hygrometer. Daily egg mass loss and eggshell conductance were calculated for every 10 eggs randomly chosen per breeder age during the first week of incubation. Eggshell conductance $\left(\mathrm{mg} \mathrm{H}_{2} \mathrm{O}\right.$ per day per $\mathrm{mm} \mathrm{Hg}$ ) was obtained by dividing daily egg mass loss by a saturation vapor conductance of $23.86 \mathrm{~mm} / \mathrm{Hg}$ at $25^{\circ} \mathrm{C}$ (Rahn et al., 1981), correcting the values to a barometric pressure of 1 atmosphere, as described by Ar et al. (1974).

Body, heart, and liver weights, and blood parameters were analyzed according to a completely randomized experimental design with a 2 (sex: male and female) $\times 2$ (breeder age: 30 and 60 wk of age) $\times$ 
Morita VS, Boleli IC, Cargnelutti Filho A

4 (embryo age: 13, 15, 18, and 21 days of incubation) factorial arrangement. Three hundred eggs (150 eggs per breeder age) were placed in four incubators (two per breeder age) (IP70, Premium Ecológica), maintained at $37.5^{\circ} \mathrm{C}$ and $60 \% \mathrm{RH}$ controlled by a hygrometer until hatching, and turned every two hours.

On days 13, 15 and 18 of incubation, blood samples were collected from the yolk pedicle, whereas at 21 days of incubation (corresponding to newly-hatched chicks, which were used as soon as the down dried) blood samples were collected from jugular vein $(\mathrm{N}=6$ embryos/day of incubation/breeder age). Blood samples were placed in plastic vials containing EDTA (GLISTAB, $15 \mu \mathrm{l} / \mathrm{ml}$ blood), stored on ice, and submitted to the lab in order to determine hematocrit (HCT, \%), red blood cell count (RBC, $\left.x \mathrm{~mm}^{3} / \mathrm{mL}\right)$, hemoglobin ( $\left.\mathrm{HGB}, \mathrm{g} / \mathrm{dL}\right)$, mean corpuscular volume (MCV, $\left.\mu^{3}\right)$, and plasma glucose (mg/ $\mathrm{dL}$ ). Erythrocytic values were obtained using a blood-cell counter (Celm, Mod. 550), with two readings per bird $(20 \mu \mathrm{L}$ of blood per reading). For glucose determination, blood samples were centrifuged at $1.500 \mathrm{rpm}$ at $4^{\circ} \mathrm{C}$ for 15 min. Plasma samples were placed in plastic vials and stored at $-20^{\circ} \mathrm{C}$ until analysis. Plasma glucose was determined using a glucose PAP liquiform kit (Labtest, Cat. N.84). Two readings per embryo were carried out at $505 \mathrm{~nm}$. Specific leukocytes were counted in blood smears stained with Rosenfeld solution. Monocyte, lymphocyte, heterophil, eosinophil, and basophil counts were determined by counting the number of each
Hematological Values and Body, Heart and Liver Weights of Male and Female Broiler Embryos of Young and Old Breeder Eggs leukocyte type in 100 analyzed cells, and expressed as estimated percentages of the 100 analyzed cells.

Immediately after blood collection, embryos were weighed (without the yolk sac), as well as their livers and hearts (Marte, $0.0001 \mathrm{~g}$ ). Relative heart and liver weights were calculated as a percentage of embryo body weight.

Egg physical characteristics were analyzed by thetstudent test $(p<0.05)$. A $2 \times 2 \times 4$ factorial arrangement was employed to analyze weights and erythrocytic parameters. Data were analyzed for outliers and tested for normality and variance. All analyses were performed using the GLM procedure of SAS package (2002), with a different number of replications. The fitted means were compared by the F-test and Tukey's test $(p<0.05)$.

\section{RESULTS AND DISCUSSION}

Table 1 shows egg physical parameter data. All analyzed physical parameters were lower $(p<0.05)$ in eggs from 29-wk-old as compared to those of 60-wkold breeders (29WB and 60WB, respectively), except for relative eggshell weight and eggshell thickness, which were lower $(p<0.05)$ in 60WB eggs than in 29WB eggs, and egg density, which was not significantly different( $p>0.05)$ between breeder ages.

The similar density observed between 29WB eggs and 60WB eggs resulted from a proportional increase

\begin{tabular}{|c|c|c|c|c|c|c|c|}
\hline & $\begin{array}{l}\text { IM } \\
(g)\end{array}$ & $\begin{array}{l}M \times D \\
(\mathrm{~cm})\end{array}$ & $\begin{array}{l}\operatorname{Min} D \\
(\mathrm{~cm})\end{array}$ & $\begin{array}{c}\mathrm{SA} \\
\left(\mathrm{cm}^{2}\right)\end{array}$ & $\begin{array}{c}\text { Vol } \\
\left(\mathrm{cm}^{3}\right)\end{array}$ & $\begin{array}{c}D \\
\left(\mathrm{~g} / \mathrm{cm}^{3}\right)\end{array}$ & $\begin{array}{l}\text { ASW } \\
(g)\end{array}$ \\
\hline$p$ & $<0.0001$ & $<0.0001$ & $<0.0001$ & $<0.0001$ & $<0.0001$ & 0.8433 & $<0.0001$ \\
\hline T & -14.5665 & -8.1335 & -5.4012 & -14.3951 & -14.8790 & 0.2005 & -7.9111 \\
\hline 29WB & $56.2 b$ & $5.3 \mathrm{~b}$ & $4.0 \mathrm{~b}$ & 69.6 b & $52.5 b$ & $1.0 \mathrm{a}$ & $5.2 \mathrm{~b}$ \\
\hline \multirow[t]{2}{*}{$60 \mathrm{WB}$} & $74.7 \mathrm{a}$ & $6.1 \mathrm{a}$ & $4.3 \mathrm{a}$ & $84.1 \mathrm{a}$ & $70.0 \mathrm{a}$ & $1.0 \mathrm{a}$ & $6.7 \mathrm{a}$ \\
\hline & $\begin{array}{l}\text { RSW } \\
(\%)\end{array}$ & $\begin{array}{l}\text { SVol } \\
(\mathrm{ml})\end{array}$ & $\begin{array}{c}\text { MST } \\
(\mathrm{mm})\end{array}$ & $\begin{array}{c}\text { STP } \\
(\mathrm{mm})\end{array}$ & $\begin{array}{l}\text { STE } \\
(\mathrm{mm})\end{array}$ & $\begin{array}{c}\text { STL } \\
(\mathrm{mm})\end{array}$ & TPN \\
\hline$p$ & $<0.0001$ & $<0.0001$ & 0.0094 & 0.0007 & 0.0238 & 0.0029 & 0.0114 \\
\hline $\mathrm{T}$ & -14.3951 & -6.0511 & -1.734 & -4.0521 & -2.4673 & -3.4324 & 2.1100 \\
\hline 29WB & $9.3 \mathrm{a}$ & $3.2 \mathrm{~b}$ & $0.6 \mathrm{a}$ & $0.6 \mathrm{a}$ & $0.6 \mathrm{a}$ & $0.6 \mathrm{a}$ & $1741 b$ \\
\hline \multirow[t]{2}{*}{$60 \mathrm{WB}$} & $9.0 \mathrm{~b}$ & $4.9 \mathrm{a}$ & $0.5 \mathrm{~b}$ & $0.4 \mathrm{~b}$ & $0.5 \mathrm{~b}$ & $0.5 \mathrm{~b}$ & 2364 a \\
\hline & $\begin{array}{c}\text { PNP } \\
\left(\text { pore } / \mathrm{cm}^{2}\right)\end{array}$ & $\begin{array}{c}\text { PNE } \\
\left(\text { pore } / \mathrm{cm}^{2}\right)\end{array}$ & $\begin{array}{c}\text { PNL } \\
\left(\text { pore } / \mathrm{cm}^{2}\right)\end{array}$ & $\begin{array}{c}\text { MPN } \\
\left(\text { pore } / \mathrm{cm}^{2}\right)\end{array}$ & $\begin{array}{c}\text { CON } \\
(g)\end{array}$ & $\begin{array}{l}\text { TWL } \\
\text { (g) }\end{array}$ & $\begin{array}{l}\text { DWL } \\
(g)\end{array}$ \\
\hline$p$ & 0.1293 & 0.4765 & 0.7533 & 0.2279 & $<0.0001$ & 0.2371 & 0.0001 \\
\hline T & -1.5893 & -0.7270 & -0.3190 & -1.2481 & 1.985 & -1.9762 & 1.5521 \\
\hline 29WB & $24.8 \mathrm{a}$ & $23.6 \mathrm{a}$ & $26.8 \mathrm{a}$ & $25.1 \mathrm{a}$ & $11.6 \mathrm{~b}$ & $0.28 \mathrm{a}$ & 1.39 b \\
\hline $60 W B$ & $31.4 \mathrm{a}$ & $26.7 \mathrm{a}$ & 27.6 a & $28.6 \mathrm{a}$ & 14.9 a & 0.31 a & 1.78 a \\
\hline
\end{tabular}

SA: surface area, MxD and MinD: maximum and minimum diameters, D: density, IM: initial mass, DWL and TWL: daily and total water loss, Vol: volume of eggs. CON: eggshell conductance; STP, STE and STL: shell thickness in the pointed end, equatorial and widest regions of the egg; MST: mean eggshell thickness; TPN: total pore number; PNP, PNE and PNL: pore number in the pointed end, equatorial and widest regions of the egg; ASW and RSW: absolute and relative eggshell weights; SVol: eggshell volume. a-b: means followed by similar letters in the same column are not significantly different $(p<0.05)$ by t-student test. 
Morita VS, Boleli IC, Cargnelutti Filho A in egg mass and volume in both ages. According to Woods (1999), when there is an isometric increase in size, volume increases more rapidly than surface area. The results of the present study show a mean difference of approximately $17.5 \mathrm{~cm}^{3}$ in volume and of $14.5 \mathrm{~cm}^{2}$ in surface area between 29WB and 60WB eggs, corresponding to an increment of $33.3 \%$ in volume and of $21 \%$ in surface area of eggs in a 31 -wk interval (between 29 and 60 weeks of age). These data suggest an isometric growth in egg size, and show a lower surface:volume ratio in 29WB eggs as compared to 60WB eggs (1.32 and 1.20, respectively). Eggshell volume increased $50.8 \%$ between 29 and 60 weeks of age, while egg volume increased only $33 \%$, resulting from the reduction in relative eggshell weight during the same period.

The data relative to eggshell thickness obtained in the present study agrees with those of Maiorka et al. (2003), who also found that eggshell thickness decreases with breeder age. According to Baião \& Aguilar (2001), calcium content remains constant in the eggshell during the laying cycle, which may explain the lower mean eggshell thickness observed in eggs from older breeders as compared to younger breeders. In the present study, we verified a high positive correlation between eggshell thickness and weight, as well as between eggshell thickness and egg longitudinal axis, volume, and surface area, indicating that eggshell thickness reduction is related to the physical dimensions of the eggs.

An equal number of pores per $\mathrm{cm}^{2}$ was observed in the three analyzed areas of the eggshell, independently
Hematological Values and Body, Heart and Liver Weights of Male and Female Broiler Embryos of Young and Old Breeder Eggs

of breeder age, in the present experiment. Eggshells from 29-wk-old breeders, however, presented a lower total pore number than those from 60-wk-old breeders. This higher egg porosity in older breeders, however, results from the higher volume and surface area of their eggshells. 60WB eggs had lower eggshell thickness, and higher porosity and conductance. Considering that conductance corresponds to capacity of gas exchange between the internal and external egg environment, and that gas exchanges are related to water mass loss (Campos et al., 2003), the higher conductance reported in 60WB eggs resulted simultaneously from their higher pore number and lower shell thickness. Increases in conductance and water loss during incubation were also observed by $\mathrm{Ar}$ \& Rahn (1980).

There was significant interaction $(p<0.05)$ between breeder age and sex, and breeder and embryo age for absolute (ABW) and relative (RBW) body weights (Tables 2 and 3). Independently of the breeder age, males and females were not different as to ABW and RBW, and both presented higher $A B W$ and lower RBW when derived from 60WB eggs as compared to 29WB eggs. Embryo $A B W$ and RBW increased continuously and significantly $(p<0.05)$ after day 13 of incubation in both breeder ages. At day 18 of incubation, embryos from 29WB eggs had higher RBW $(p<0.05)$ than those from 60WB eggs, and at day 21, their ABW was lower $(p<0.05)$. The absence of any significant difference in RBW between males and females, and between the two breeder ages at hatching shows that the body

Table 2- Effects of embryo age (13,15, 18 and 21 days of incubation), sex and breeder age (29 and 60 weeks of age: 29WB and 60WB, respectively) on absolute (ABW, g) and relative (RBW, \%) body weights; absolute (ALW, g) and relative (RLW, \%) liver weights; absolute $(\mathrm{AHW}, \mathrm{g})$ and relative (RHW, \%) heart weights of broiler embryos.

\begin{tabular}{|c|c|c|c|c|c|c|}
\hline & ABW & RBW & ALW & RLW & $\mathrm{AHW}$ & RHW \\
\hline \multicolumn{7}{|c|}{ Embryo age (EA) } \\
\hline 13 & $9.11 \mathrm{a}$ & $14.19 \mathrm{a}$ & $0.15 \mathrm{a}$ & $1.65 \mathrm{~b}$ & $0.06 \mathrm{a}$ & $0.68 \mathrm{~b}$ \\
\hline 15 & $15.47 \mathrm{a}$ & $24.29 \mathrm{a}$ & $0.29 \mathrm{a}$ & $1.90 \mathrm{a}$ & $0.13 \mathrm{a}$ & $0.84 \mathrm{a}$ \\
\hline 18 & 27.89 a & $37.00 \mathrm{a}$ & $0.57 \mathrm{a}$ & $2.04 \mathrm{a}$ & $0.20 \mathrm{a}$ & $0.73 \mathrm{~b}$ \\
\hline $21 *$ & 49.48 a & $75.17 \mathrm{a}$ & $0.80 \mathrm{a}$ & $1.63 b$ & $0.26 \mathrm{a}$ & $0.53 c$ \\
\hline \multicolumn{7}{|l|}{ Sex (S) } \\
\hline Male & $26.03 \mathrm{a}$ & $37.15 \mathrm{a}$ & $0.49 a$ & $1.79 \mathrm{a}$ & $0.17 \mathrm{a}$ & $0.68 \mathrm{a}$ \\
\hline Female & $24.95 \mathrm{a}$ & $38.16 \mathrm{a}$ & $0.47 \mathrm{a}$ & $1.80 \mathrm{a}$ & $0.17 \mathrm{a}$ & $0.69 \mathrm{a}$ \\
\hline \multicolumn{7}{|c|}{ Breeder age (BA) } \\
\hline $29 W B$ & $23.88 \mathrm{a}$ & $40.15 a$ & $0.42 \mathrm{a}$ & $1.80 \mathrm{a}$ & $0.14 \mathrm{a}$ & $0.65 \mathrm{a}$ \\
\hline $60 W B$ & $27.1 \mathrm{a}$ & 34.79 a & $0.48 \mathrm{a}$ & $1.79 \mathrm{a}$ & $0.17 \mathrm{a}$ & $0.72 \mathrm{a}$ \\
\hline \multicolumn{7}{|c|}{ Probability } \\
\hline EA & $<0.0001$ & $<0.0001$ & $<0.0001$ & $<0.0001$ & $<0.0001$ & $<0.0001$ \\
\hline$S$ & $<0.0001$ & $<0.0001$ & 0.4043 & 0.6135 & 0.6729 & 0.6135 \\
\hline BA & $<0.0001$ & $<0.0001$ & $<0.0001$ & 0.6904 & $<0.0001$ & 0.6904 \\
\hline$B A \times S$ & 0.0076 & 0.0487 & 0.0500 & 0.4729 & 0.3445 & 0.4729 \\
\hline$B A \times E A$ & $<0.0001$ & 0.0023 & $<0.0001$ & 0.2362 & 0.0051 & 0.2362 \\
\hline$S \times E A$ & 0.3307 & 0.7956 & 0.9318 & 0.4454 & 0.0553 & 0.4454 \\
\hline
\end{tabular}

a-d: means followed by similar letters in the same column are not significantly different $(p<0.05)$ by Tukey's test and analysis of variance. ${ }^{\star}$ Newlyhatched chicks. 


\section{Morita VS, Boleli IC, Cargnelutti} Filho A weight of newly-hatched chicks was equivalent to approximately $75 \%$ of the initial egg mass. This value is consistent with the interval $(75-80 \%)$ considered normal for chicks by Henry \& Burke (1997).

\begin{tabular}{|c|c|c|c|c|}
\hline \multicolumn{5}{|c|}{$\begin{array}{l}\text { Table } 3 \text { - Interaction between breeder a } \\
60 W B \text { weeks of age) and sex (male an } \\
(A B W) \text { and relative (RBW) body weights, a } \\
\text { breeder and embryo age }(13,15,18 \text {, and } \\
\text { for ABW, RBW, absolute liver weight (ALV } \\
\text { heart weights. } \\
\text { B B W }\end{array}$} \\
\hline & 29WB & $60 \mathrm{WB}$ & 29WB & $60 \mathrm{WB}$ \\
\hline Male & $23.92 \mathrm{Ba}$ & $28.14 \mathrm{Aa}$ & $40.61 \mathrm{Aa}$ & $33.70 \mathrm{Ba}$ \\
\hline Female & $23.82 \mathrm{Ba}$ & $26.06 \mathrm{Aa}$ & $40.45 \mathrm{Aa}$ & $35.88 \mathrm{Ba}$ \\
\hline \multicolumn{5}{|c|}{ Breeder age $X$ Embryo age } \\
\hline & 29WB & $60 \mathrm{WB}$ & 29WB & 60WB \\
\hline 13 & $8.90 \mathrm{Ad}$ & $9.30 \mathrm{Ad}$ & $15.44 \mathrm{Ad}$ & $12.94 \mathrm{Ad}$ \\
\hline 15 & 15.27 AC & $15.68 \mathrm{Ac}$ & $26.56 \mathrm{Ac}$ & $22.01 \mathrm{Ac}$ \\
\hline 18 & $26.69 \mathrm{Ab}$ & $29.10 \mathrm{Ab}$ & $44.47 \mathrm{Ab}$ & $29.54 \mathrm{Ba}$ \\
\hline \multirow[t]{3}{*}{$21^{*}$} & $44.65 \mathrm{Ba}$ & $54.32 \mathrm{Aa}$ & $75.66 \mathrm{Aa}$ & $74.83 \mathrm{Aa}$ \\
\hline & \multicolumn{2}{|c|}{ ALW } & \multicolumn{2}{|c|}{ AHW } \\
\hline & 29WB & $60 \mathrm{WB}$ & $29 W B$ & $60 \mathrm{WB}$ \\
\hline 13 & $0.05 \mathrm{Ad}$ & $0.06 \mathrm{Ad}$ & $0.15 \mathrm{Ad}$ & $0.14 \mathrm{Ad}$ \\
\hline 15 & $0.12 \mathrm{Ab}$ & $0.13 \mathrm{Ab}$ & $0.28 \mathrm{Ac}$ & $0.31 \mathrm{Ac}$ \\
\hline 18 & $0.18 B C$ & $0.21 \mathrm{Ac}$ & $0.54 \mathrm{Ab}$ & $0.59 \mathrm{Ab}$ \\
\hline 21 * & $0.23 \mathrm{Ba}$ & $0.28 \mathrm{Aa}$ & $0.72 \mathrm{Ba}$ & $0.88 \mathrm{Aa}$ \\
\hline
\end{tabular}

$a-b$ (columns), A-B (lines): means followed by similar letters are not significantly different $(p<0.05)$ by Tukey's test and analysis of variance.. *Newly-hatched chicks.

The observed significant interaction $(p<0.05)$ between embryo and breeder ages shows that the absolute liver weight (ALW) increased continuously and significantly $(p<0.05)$ from day 13 of incubation in embryos from 29WB and 60WB eggs. At days 18 and 21, ALW was higher $(p<0.05)$ in embryos from 60WB eggs than from 29WB. Relative liver weight was significantly influenced $(p<0.05)$ only by embryo age (Table 2), increasing between day 13 and 15 of incubation and from day 18 to hatching. For absolute heart weight $(A H W)$, there was a significant $(p<0.05)$ interaction between embryo and breeder ages (Table 2 and 3), showing that AHW continuously increased during the incubation period, reaching higher values in newlyhatched chicks from 60WB eggs than those from 29WB eggs. Relative heart weight was significantly influenced $(p<0.05)$ only by embryo age, increasing between day 13 to 15 of incubation, and decreasing from day 15 to hatching, and reaching the lowest values at hatching as compared to the other three analyzed ages.

Data relative to ALW and AHW show that both organs gradually grow during the second half of the
Hematological Values and Body, Heart and Liver Weights of Male and Female Broiler Embryos of Young and Old Breeder Eggs incubation period, independently of sex or breeder age. In addition, it was shown that RLW is not related to breeder age, as previously observed by Maiorka et al. (2000), or to embryo sex. In broilers (Nichelmann et al., 1998; Decuypere et al., 1979) and in emus (Prinzinger et al., 1997), energy production, and consequently, metabolism, markedly increases from day 10 of incubation on. Therefore, the higher liver weight values determined at days 15 and 18 of incubation seem to be related with the higher metabolic activity presented by the embryos during the last quarter of incubation.

Increases in environmental oxygen during the last quarter of incubation increases oxygen consumption, as well as embryo growth and survival (Tazawa et al., 1992; Christensen et al., 1997). It is known that a lower number of pores per egg limits the oxygen available for the embryo (Tullett \& Deeming, 1982) and reduces its growth rate (Burton \& Tullett, 1983). In avian embryos, higher oxygen consumption and, consequently, higher metabolic rates and gas exchange, depends on two structural eggshell features: thickness and pore number. Therefore, the higher body, liver, and heart weights recorded in embryos from 60WB eggs seems to be related to the lower thickness and the higher porosity and conductance of the eggshell of 60WB eggs.

Tables 4 and 5 show the erythrogram results. No significant $(p<0.05)$ effect of sex or breeder age was observed on RBC, MCV and HGB, but these parameters were significantly $(p<0.05)$ influenced by embryo age. RBC and HGB values increased both between days 13 and 15 of incubation and days 18 and 21 , reaching the highest values at hatching. MCV values were lower at 21 than at 13 days of incubation. There was no effect of breeder age on HCT, but a significant $(p<0.05)$ interaction between sex and embryo age was observed, showing that both female and male HCT values increased from days 13 to 15 and days 18 to 21 of incubation, reaching the highest values at hatching; however, males had higher HCT values than the females at 15 and 21 days.

In broilers (Nichelmann et al., 1998; Decuypere et al., 1979) and in emus (Prinzinger et al., 1997), heat production, as estimated by oxygen consumption, and therefore metabolism, markedly increases in the second half of the incubation period. This indicates that the higher RBC, HCT and HGB values recorded in embryos after day 13 in the present study are related to a higher embryonic metabolic rate during this period. The positive correlations between these erythrocytic parameters and heart weight during the incubation 
Morita VS, Boleli IC, Cargnelutti Filho A

period suggest an adaptation of heart mass to changes in heart potential (output) related to increases in metabolic and respiratory rates during this period, according to Decuypere (1979). As already mentioned here, with isometrical increases in size, volume increases more rapidly than surface area (Woods, 1999), indicating that lower MCV values imply in higher erythrocyte surface areas. Therefore, it is possible that the reduction in the MCV values presented by the embryos at the end of incubation (our data) is related to an increase in oxygen supply, in an attempt to supply the increasing embryonic oxygen demand resulting from the higher embryonic metabolic rate after day 13 of incubation. Therefore, the results of the present study indicate that older embryos respond to higher oxygen demand resulting from their higher metabolic rate elevating oxygen transportation rate by increasing their cardiac output and also reducing their blood cell volume.

Table 4- Effects of embryo age $(13,15,18$, and 21 days of incubation), sex and breeder age (29: 29WB and 60: 60WB weeks of age) on red blood cell counts (RBC, $\left.10^{6} / \mathrm{mm}^{3}\right)$, mean corpuscle volume (MCV, $\mu \mathrm{m}^{3}$ ), hematocrit ( $\left.\mathrm{HCT}, \%\right)$, hemoglobin (HGB, g/ $\mathrm{dl})$, and plasma glucose concentration (PG, $\mathrm{mg} / \mathrm{dl})$.

\begin{tabular}{|c|c|c|c|c|c|}
\hline & RBC & VCM & HCT & HGB & PG \\
\hline \multicolumn{6}{|c|}{ Embryo age (EA) } \\
\hline 13 & $0.45 c$ & $134.08 b$ & 5.61 & $2.8 \mathrm{c}$ & $0.18 c$ \\
\hline 15 & $1.23 \mathrm{bc}$ & $127.29 \mathrm{ab}$ & 15.29 & $6.5 b$ & $0.17 c$ \\
\hline 18 & $1.54 \mathrm{~b}$ & $126.85 \mathrm{ab}$ & 15.92 & $7.33 \mathrm{~b}$ & $0.31 \mathrm{~b}$ \\
\hline $21 *$ & $2.57 \mathrm{a}$ & 123.8 a & 25.88 & $16.01 \mathrm{a}$ & $0.49 a$ \\
\hline \multicolumn{6}{|l|}{$\operatorname{Sex}(S)$} \\
\hline Male & $1.59 \mathrm{a}$ & $128.96 a$ & $17.47 \mathrm{a}$ & $9.2 \mathrm{a}$ & $0.28 \mathrm{a}$ \\
\hline Female & $1.29 \mathrm{a}$ & $127.44 \mathrm{a}$ & $13.88 \mathrm{a}$ & $7.11 \mathrm{a}$ & $0.28 a$ \\
\hline \multicolumn{6}{|c|}{ Breeder age (BA) } \\
\hline $29 W B$ & $1.33 \mathrm{a}$ & $127.74 \mathrm{a}$ & $15.77 \mathrm{a}$ & $6.82 \mathrm{a}$ & $0.29 \mathrm{a}$ \\
\hline $60 \mathrm{WB}$ & $1.55 \mathrm{a}$ & $128.66 \mathrm{a}$ & $15.59 \mathrm{a}$ & $9.49 a$ & $0.28 \mathrm{a}$ \\
\hline \multicolumn{6}{|c|}{ Probabilility } \\
\hline EA & $<0.0001$ & 0.0308 & $<0.0001$ & $<0.0001$ & $<0.0001$ \\
\hline S & 0.1701 & 0.7369 & 0.0956 & 0.6622 & 0.9420 \\
\hline BA & 0.3131 & 0.6635 & 0.1055 & 0.1637 & 0.5883 \\
\hline$B A \times S$ & 0.7846 & 0.7893 & 0.8332 & 0.3791 & 0.7843 \\
\hline$B A \times E A$ & 0.7017 & 0.5087 & 0.5369 & 0.3554 & 0.6696 \\
\hline$S \times E A$ & 0.8829 & 0.6921 & 0.0067 & 0.1276 & 0.1399 \\
\hline
\end{tabular}

a-c: means followed by similar letters in the same column are not significantly different $(p<0.05)$ by Tukey's test and analysis of variance. *Newly-hatched chicks.

Table 5- Interaction between embryo sex and age (13, 15, 18, and 21 days of incubation) on hematocrit (HCT, \%).

\begin{tabular}{ccc}
\hline \multirow{2}{*}{ Embryo age } & \multicolumn{2}{c}{ Sex } \\
\cline { 2 - 3 } & \multicolumn{1}{c}{ Male } & Female \\
\hline 13 & $6.28 \mathrm{Ac}$ & $4.95 \mathrm{Ac}$ \\
15 & $17.78 \mathrm{Ab}$ & $12.81 \mathrm{Bb}$ \\
18 & $16.83 \mathrm{Ab}$ & $15.03 \mathrm{Ab}$ \\
$21^{*}$ & $29.01 \mathrm{Aa}$ & $22.76 \mathrm{Ba}$ \\
\hline
\end{tabular}

a-c (columns), A-B (lines): means followed by similar letters are not significantly different $(p<0.05)$ by Tukey's test and analysis of variance. *Newly-hatched chicks.
Hematological Values and Body, Heart and Liver Weights of Male and Female Broiler Embryos of Young and Old Breeder Eggs
Plasma glucose (PG) values were not influenced ( $p>0.05$ ) by embryo sex or breeder age, suggesting that embryonic carbohydrate metabolism as a function of embryo sex or breeder age did not result in any PG changes during embryo development. However, there was a significant $(p<0.05)$ effect of embryo age on PG (Table 4). PG values remained unchanged until day 15 of incubation, and consistently increased between day 15 and 21. This increase in PG during incubation was also observed by Christensen et al. (2003). According to Christensen et al. (2001), during late incubation, oxygen demand by the embryonic tissues exceed oxygen conductance through the eggshell. During this period, more carbohydrate is required because of the higher oxygen demand of lipid metabolism (Pearce and Brown, 1971), which becomes the essential substrate during shell pipping (Freeman, 1965). Energy derived of anaerobic metabolism is necessary to sustain body growth and maintenance. However, if this energy is limiting, the embryo will have to choose between growth and vital activity maintenance (Ricklefs, 1987).

Our results are different from those obtained in turkeys by Christensen et al. (1996), which showed that embryonic blood plasma glucose concentrations declined as hens aged, but are consistent with the findings of Christensen et al. (2000). Also working with turkeys, the authors verified that PG values are correlated with body weight at hatching day. A significant $(p<0.05)$ positive correlation $(r=0.8765)$ between body weight and PG was found during embryonic development, independently of breeder age. Newly-hatched chicks derived from 60WB eggs were heavier than those of 29WB eggs, but there was no difference in their PGs. Therefore, despite the observed correlation between chick weight and PG, the absence of breeder age-related differences in the PG values indicates that the higher PG values observed during the last days of incubation are not related to body mass gain, but to the energy demands of tissue metabolism during the period of change from chorioallantoic to pulmonary respiration.

Data relative to differential leukocyte counts are presented in Table 6 . There were no significant $(p<0.05)$ effects of breeder age or sex on the counts of the different leukocyte types. There was influence embryo age only on monocyte, limphocyte and thrombocyte values. Monocyte counts were higher at day 15 as compared to the other three analyzed ages, which were not different from each other. Also, there were no differences in the lymphocyte counts between days 13 and 15 , or between days 18 and 21; however, 
Table 6- Effects of embryo age (13, 15, 18 and, 21 days of incubation), and sex, and breeder age (29: 29WB and 60: 60WB weeks of age) on differential leukocyte counts and $\mathrm{H} / \mathrm{L}$ ratios in broiler embryos.

\begin{tabular}{|c|c|c|c|c|c|c|c|c|}
\hline \multirow{2}{*}{\multicolumn{2}{|c|}{ Embryo age }} & \multirow{2}{*}{ Monocytes } & \multirow{2}{*}{ Basophils } & \multirow{2}{*}{ Eosinophils } & \multirow{2}{*}{ Heterophils } & \multirow{2}{*}{ Lymphocytes } & \multirow{2}{*}{ Trombocytes } & \multirow{2}{*}{$\mathrm{H} / \mathrm{L}$} \\
\hline & & & & & & & & \\
\hline & 13 & $1.49 \mathrm{~B}$ & $2.09 \mathrm{~A}$ & $0.61 \mathrm{~A}$ & $13.05 \mathrm{~A}$ & $13.97 \mathrm{~B}$ & $64.93 \mathrm{~A}$ & $0.79 \mathrm{~A}$ \\
\hline & 15 & $3.56 \mathrm{~A}$ & $7.23 \mathrm{~A}$ & $0.80 \mathrm{~A}$ & $2.89 \mathrm{~A}$ & $4.46 \mathrm{~B}$ & $73.90 \mathrm{~A}$ & $0.56 \mathrm{~A}$ \\
\hline \multirow[t]{3}{*}{18} & $1.65 \mathrm{~B}$ & $2.44 \mathrm{~A}$ & $1.51 \mathrm{~A}$ & $9.01 \mathrm{~A}$ & 38.54 A & $48.69 \mathrm{~B}$ & $0.24 \mathrm{~A}$ & \\
\hline & $21 *$ & $0.80 \mathrm{~B}$ & $7.08 \mathrm{~A}$ & $1.10 \mathrm{~A}$ & $13.71 \mathrm{~A}$ & $31.19 \mathrm{~A}$ & $53.86 \mathrm{~B}$ & $1.09 \mathrm{~A}$ \\
\hline & $p$ & 0.0500 & 0.5074 & 0.3386 & 0.5698 & 0.0005 & 0.0152 & 0.7886 \\
\hline \multicolumn{9}{|c|}{ Sex } \\
\hline & Male & $1.68 \mathrm{~A}$ & $3.14 \mathrm{~A}$ & $0.90 \mathrm{~A}$ & $7.41 \mathrm{~A}$ & 29.79 A & $59.89 \mathrm{~A}$ & $1.03 \mathrm{~A}$ \\
\hline & Female & $1.41 \mathrm{~A}$ & $5.93 \mathrm{~A}$ & $1.01 \mathrm{~A}$ & $14.41 \mathrm{~A}$ & 20.99 A & $55.93 \mathrm{~A}$ & $0.41 \mathrm{~A}$ \\
\hline & $p$ & 0.6591 & 0.3800 & 0.8234 & 0.1623 & 0.1463 & 0.4697 & 0.3415 \\
\hline \multicolumn{9}{|c|}{ Breeder age } \\
\hline & $29 W B$ & $1.26 \mathrm{~A}$ & $1.91 \mathrm{~A}$ & $1.03 \mathrm{~A}$ & $8.01 \mathrm{~A}$ & $21.07 \mathrm{~A}$ & $58.52 \mathrm{~A}$ & $0.45 \mathrm{~A}$ \\
\hline & $60 \mathrm{WB}$ & $1.85 \mathrm{~A}$ & $7.51 \mathrm{~A}$ & $0.87 \mathrm{~A}$ & $14.27 \mathrm{~A}$ & $30.02 \mathrm{~A}$ & $57.16 \mathrm{~A}$ & $1.02 \mathrm{~A}$ \\
\hline & $p$ & 0.3406 & 0.0753 & 0.7601 & 0.2125 & 0.1404 & 0.8046 & 0.3819 \\
\hline
\end{tabular}

A-C: Means followed by similar letters in the same column are not significantly different $(p<0.05)$ by Tukey's test . ${ }^{*}$ : Newly-hatched chicks.

counts were higher in the latter than in the former. Thrombocyte counts between days 13 and 15 , and days 18 and 21 were also similar, but in contrast with lymphocytes, a significant $(p<0.05)$ decrease in thrombocyte counts was observed between day 15 and 18 , resulting in lower values in the last days of incubation.

Heterophils, basophils and eosinophils do not present antigenic specificity, but they have an important role in the acute phase of infection (Charles Noruega, 2000). In the present study, the counts of these three cell types were very low during all periods, probably as a result of a contamination-free incubation.

Thrombocytes were markedly the most frequent leukocyte in the blood during incubation. This finding is very interesting, because it characterizes an immunological difference between broiler embryos and adult birds, where heterophils are the most frequent white blood cell (Brooks et al., 1996; Kogut et al., 1998). Avian thrombocytes have intense phagocytic activity (Morgulis, 2002), which together with their high percentage concurrent with lower heterophil and lymphocyte percentages in the blood, indicates that embryos have an unspecific immunity against pathogens that invade the blood.

Thrombocytes may also have a hemostatic role (Grecchi et al., 1980). A C3b-like receptor and analogs of mammalian platelet glycoproteins IIb and IIla were identified in chicken thrombocytes (Kunicki \& Newman, 1985). Avian thrombocytes have disperse fibrinogen receptors that become focally localized when thrombocytes are activated, allowing thrombocyte aggregation (O'Toole et al., 1994). During the first half of incubation, embryonic and extra-embryonic vessels and capillary nets increase substantially by angiogenesis, which appears to create the need of high thrombocyte numbers in the embryo circulation. Avian embryos obtain nutrients and oxygen through the vitelinic and the allantoic vessels, respectively. During eggshell pipping, embryos must change from corioallantoic respiration to pulmonary respiration, a process that involves the acquisition of a new functional structure in the circulatory system and involves the development or differentiation of new vessels and the degeneration of others. Therefore, it is possible that the maintenance of high thrombocyte percentage in the embryonic blood during the entire incubation period, as observed in the present study, also ensures adequate development of the embryonic circulatory and respiratory systems, as well as allows changes in both systems required during late incubation for the adaptation to pulmonary respiration.

Lymphocytes act in specific immunity and at the beginning of adaptive reactions (Cardoso, 2003). According to Kogut et al. (1998), during egg development and immediately after hatching, birds do not have acquired immunity. However, the increase in lymphocyte percentage from day 18 of incubation on and the concurrent reduction of thrombocyte percentage during the same period found in the present study suggest the occurrence of specific immune responses and simultaneous reduction of the unspecific immune response up to hatching, which is probably essential for the exposure to the external environment.

In conclusion, our data showed that body, heart, and liver weights are influenced by maternal age, that hematocrit is influenced by embryo sex at hatching, 


\section{Morita VS, Boleli IC, Cargnelutti} Filho A and that body and organ weights, as well as red blood cell count, hematocrit, hemoglobin, plasma glucose, and lymphocytes values increase during the incubation period, whereas mean corpuscular volume and thrombocyte values decrease.

\section{REFERENCES}

$\operatorname{Ar} \mathrm{A}$, Rahn $\mathrm{H}$. Water in the avian egg: overall budget of incubation. American Zoologist 1980; 20:373-384.

Baião NC, Aguilar CAL. Manejo nutricional de reprodutoras pesadas e o impacto na qualidade do ovo e do pinto de um dia. Anais do 5th Encontro Técnico em Ciências Aviárias; 2001; Uberlândia, Minas Gerais, Brasil. p.7-24.

Barton B, Schreck CB, Barton LD. Effects of chronic cortisol administration and daily acute stress on growth. physiological conditions, and stress responses in juvenile rainbow trout. Diseases of Aquatic Organisms 1987; 2:173-185.

Burton FG, Tullett SG. A comparison of the effects of eggshell porosity on the respiration and growth of domestic fowl, duck and turkey embryos. Comparative Biochemistry Physiology 1983; 75(2):167-174.

Campos EJ, Santos JEC. O efeito de linhagens sobre o desenvolvimento embrionário. In: Macari $M$, Gonzales $E$, editores. Manejo da incubação. Jaboticabal(SP): FACTA; 2003. p.353-360.

Chamblee TN, Morgan GW, Schultz CD. Effect of refeeding shortterm deprivation of feed or water, or both. on selected physiological parameters for broiler chickens. Poultry Science 1989; 68(12):16191623.

Charles Noruega MLVC. Apuentes de hematología aviar: material didático para curso de hematologia aviária. México: Universidade Nacional Autónoma de México, Departamento de Produccíon Animal; 2000.

Christensen VL, Davis GS, Lucore LA. Eggshell conductance and other functional qualities of ostrich eggs. Poultry Science 1996; 75:1404-1410.

Christensen VL, Donaldson WE, Nestor KE. Effects of an oxygenenriched environment on the survival of turkey embryos between 25 and 28 days of age. Poultry Science 1997; 76(11):1556-1562.

Christensen VL, Grimes JL, Wineland MJ, Davis GS. Accelerating embryonic growth during incubation following prolonged egg storage 2. Embryonic growth and metabolism. Poultry Science 2003; 82(12):1869-1878.

Christensen VL, Havenstein GB, Davis GS. Egg characteristics, carbohydrate metabolism and thyroid hormones in the late chickembryos from different genetic lines. Poultry Science 1995; 74(2):551-562.

Christensen VL, Mc Murtry JP, Donaldson WE, Lerner S. Correlation of body weight with hatchling blood glucose concentration and its
Hematological Values and Body, Heart and Liver Weights of Male and Female Broiler Embryos of Young and Old Breeder Eggs

relationship to embryonic survival. Poultry Science 2000; 79(12): 1817-22.

Christensen VL, McMurtry JP, Donaldson WE, Nestor KE. Incubation temperature affects plasma insulin-like growth factors in embryos from selected lines of turkeys. Poultry Science 2001; 80:949-954.

Decuypere E, Nouwen EJ, Kühn ER, Geers R, Michels H. lodohormones in the serum of chick embryos and post-hatching chickens as influenced by incubation temperature. Relationship with the hatching process and thermogenesis. Annales de biologie animale, biochimie et biophisique 1979; 19:1713-1723.

Freeman BM. The importance of glycogen at the termination of the embryonic existence in Gallus domesticus. Comparative Biochemistry and Physiology 1965; 28:1169-1170.

Grecchi R, Saliba AM, Mariano M. Morphological changes, surface receptors and phagocytic potential of fowl mononuclear phagocytes and thrombocytes in vivo and in vitro. Journal of Pathology 1980; $130: 23-31$

Gualhanone A. Estudo da variação da temperatura de superfície da casca de ovos provenientes de matrizes de 30 e 60 semanas de idade durante a incubação [dissertação]. Jaboticabal (SP): Universidade Estadual Paulista; 2002.

Henry MH, Burke WH. Sexual Dimorphism in broiler chick embryos and embryonic muscle development in late incubation. Poultry Science 1997; 77:728-736.

Kogut MH, Lowry K, Moyses RB, Bowden R, Genovese K, Deloach $J R$. Lympholine-augmented activation of avian heterophils. Poultry Science 1998; 77:964-971.

Kunicki. TJ, Newman PJ. Synthesis of analogs of human-platelet membrane glycoprotein-IIA-IIIA complex by chicken peripheralblood thrombocytes. Proceeding of the National Academy of Science 1985: 82(21):7319-7323.

La Scala Jr N. Aspectos físicos da incubação. In: Macari M, Gonzales E, editores. Manejo da incubação: incubação artificial. Jaboticabal(SP): FACTA; 2003. p.353-360.

Maiorka A, Luquetti BC, Almeida JG, Macari M. Idade da matriz e qualidade do pintainho. In: Macari M, Gonzales E, editores. Manejo da incubação: fatores que afetam a eclodibilidade e qualidade dos pintos. Jaboticabal(SP): FACTA; 2003. p. 361-377.

Maiorka A, Santin E, Silva AVF, Bruno LDG, Boleli IC, Macari M. Influence of broiler breeders age (30 and 60 weeks) on embryonic gastrointestinal development. Brazilian Journal Poultry Science 2000; 2:141-48.

Maxwell MH, Robertson GW, Spence S, McCorquodale CC. Comparison of haematological values in restricted- and as libitumfed domestic fowls: white blood cells and thrombocytes. British Poultry Science 1990; 31(2):399-405.

Metcalfe J, McCutcheon IE, Francisco DL, Metzenberg AB, Welch JE. Oxygen availability and growth of the chick embryo. Respiratory Physiology 1981; 46:81-88. 
Morgulis MS. Imunologia Aplicada. In: Macari M, Furlan RL, Gonzales $E$, editores. Fisiologia aviária: frangos de corte. Jaboticabal(SP): FUNEP-UNESP; 2002. p.131-246.

Nichelmann M, Burmeister A, Janke O, Höchel J, Tzschentke B. Avian embryonic thermoregulation: role of Q10 in interpretation of endothermic reactions. Journal of Thermal Biology 1998; 23(6):369-376.

Nichelmann M, Janke O, Tzschentke B. Efficiency of thermoregulation in precocial avian species during the prenatal period. Journal of Thermal Biology 2001; 26:273-280.

O'Toole ET, Hantgan RR, Lewis JC. Localization of fibrinogen during aggregation of avian thrombocytes. Experimental and Molecular Pathology 1994; 61(3):175-190.

Ohta Y, Tsushima N, Koide K, Kidd MT, Ishibashi T. Effect of amino acid injection in broiler breeder eggs on embryonic growth and hatchability of chicks. Poultry Science 1999; 78:1493-1498.

Paganelli CV, Ackerman RA, Rahn $\mathrm{H}$. The avian egg: in vivo conductance to oxygen, carbon dioxide, and water vapor in late development. In: Piiper J, editor. Respiratory function in birds, adult and embryonic. New York: Springer Verlag; 1974. p. 212-218.

Pearce J, Brown WO. Carbohydrate metabolism. In: Bell DJ, Freeman BM, editors. Physiology and biochemistry of the domestic fowl. London: Academic Press; 1971. p. 295-319.

Prizinger R, Dietz V, Nagel B. Respiratory quotient and embryological development of metabolic heat production in the Rhea (Rhea Americana). Journal of Thermal Biology 1997; 22(3):223-226.

Rahn H, Christensen VL, Edens FW. Changes in shell conductance, pore and physical dimensions of egg and shell during the first breeding cycle of turkey hens. Poultry Science 1981; 60:2536- 2540.

Rahn H, Paganelli CV, AR A. Pores and gas exchange of avian eggs: a review. Journal of Experimental Zoology 1987; 1 (supl):165-172.

Rahn H, Paganelli CV, AR A. The avian egg: air-cell gas tension Metabolism and incubation time. Respiratory Physiology 1974; 22:297-309.

Ricklefs RE. Comparative analysis of avian embryonic growth. Journal Experimental Zoology 1987; 1(Suppl):309-23.

Seymour RS, Piiper J. Aeration of the shell membranes of avian eggs. Respiratory Physiology 1988; 71:101-172.

Shanawany MM. Inter-relationship between egg weight, parental age and embryonic development. British Poultry Science 1984; 25:449-455.

Tazawa H, Hashimoto Y, Nakazaw S, Whittow GC. Metabolic responses of chicken embryos and hatchlings to altered oxygen environments. Respiratory Physiology 1992; 88(1-2):37-50.

Tullett SG, Deeming DC. The relationship between eggshell porosity and oxygen cinsumption of the embryo in the domestic fowl. Comparative Biochemistry and Physiology 1982; 72(3):529-33.
Wangensteen $\mathrm{D}$, Rahn $\mathrm{H}$. Respiratory gas exchange by the avian embryo. Respiratory Physiology 1970/1971; 11:31-45.

Wangensteen D, Weibel ER. Morphometric evaluation of chorioallantoic oxygen transport in the chick embryo. Respiratory Physiology 1982; 47:1-20.

Woods HA. Egg-mass size and cell size: effects of temperature on oxygen distribution. American Zoology 1999; 39:244-252.

Yahav S. Blood system response of chickens to changes in environmental temperature. Poultry Science 1997; 76(4):627-33. 